\title{
Toxicity Determination in Commonly Sold Soft Drink in Kazaure Town
}

\author{
Sunusi $\mathrm{S}^{1 *}$, Abdulmumin $\mathrm{Y}^{2}$ and Adamu $\mathrm{AU}^{3}$ \\ ${ }^{\mathrm{T}}$ Department of Science Laboratory Technology, College of Science and Technology Hussaini Adamu Federal \\ Polytechnic Kazaure, Jigawa State \\ ${ }^{2}$ Department of Biochemistry, Faculty of Science, Kano University of Science and Technology Wudil, Kano, Nigeria \\ ${ }^{3}$ Department of Polymer Technology, College of Science and Technology Hussaini Adamu Federal Polytechnic Kazaure, \\ Jigawa State
}

\section{*Corresponding Author \\ Sunusi S}

\section{Article History}

Received: 03.03.2020

Accepted: 10.03 .2020

Published: 14.03.2020

\begin{abstract}
This research is aimed to evaluate the level of heavy metals and pesticides residues in the commonly consumed soft drink within Kazaure town. Twenty-five (25) samples of different soft drink brands was analysed for 10 organochlorines and 6 organophosphorus pesticides. The 10 organochlorines pesticides evaluated cover wide spectrum of chlorinated pesticides. The 6 organophosphorus pesticides tested are the most commonly used pesticides. Analysis was conducted using Gas Chromatograph with Electron Capture Detector using a capillary column for analysing organochlorine pesticides and Gas Chromatograph with Nitrogen Phosphorus Detector using a capillary column for analysing organophosphorus pesticides. Final confirmation was carried out by GC-MS. While the metals were analysed using AAS. The result showed that the average concentration of all the ten (10) organochlorines pesticides evaluated were $0.11,2.99,0.22$ and $0.26 \mu \mathrm{g} / \mathrm{kg}$ for $\alpha \mathrm{HCH}, \gamma-\mathrm{HCH}, \delta$ - $\mathrm{HCH}$ and heptachlor respectively while $\beta$-HCH, DDT, Aldrin, Dieldrin Endosulfan and chlordane were not detected in all the brand of the soft drinks analyzed. The overall average of all the organochlorines pesticdes were found to be $3.71 \mu \mathrm{g} / \mathrm{kg}$. The concentration of organophosphorous pesticide were found in the 25 samples of soft drink selected, $0.74 \mu \mathrm{g} / \mathrm{kg}$ and $0.17 \mu \mathrm{g} / \mathrm{kg}$ were found as the average concentration of Chlorpyrifos and malathion respectively. While the average concentration of the total organophosphorous pesticides obtained was $0.89 \mu \mathrm{g} / \mathrm{kg}$. Chlorpyrifos and malathion were found in 48 and $44 \%$ of the 25 samples which range from 0.17 to 2.89 and 0.13 to $1.11 \mu \mathrm{g} / \mathrm{kg}$ respectively. The parathion, merphos and tricresylphosphate were not detected in all the soft drinks tested. The level of metal residue revealed that $\mathrm{Cu}, \mathrm{Cr}, \mathrm{Cd}, \mathrm{Fe}, \mathrm{Pb}, \mathrm{Zn}$ and $\mathrm{Ni}$ were found in $68 \%$, $56 \%, 36 \%, 88 \% 40 \%, 80 \%$ and $24 \%$ respectively in the 25 samples analysed. However, $\mathrm{Cu}, \mathrm{Cd}$ and $\mathrm{Zn}$ were within the permissible maximum levels(PML), while $\mathrm{Cr}, \mathrm{Fe}, \mathrm{Pb}, \mathrm{Ni}$ were found above the PML $16 \%, 48 \%, 12 \%$ and $\mathrm{Ni} 12 \%$ respectively in the 25 samples of soft drink analysed. Hence, soft drink generally can be served as source of important elements for human health and development but can be as a source of other substance like pesticide and some metals which can be toxic to human.
\end{abstract}

Keywords: Soft Drink, Heavy metal, Pesticides, Organophosphsate, Organochlorinated.

\section{INTRODUCTION}

Pesticides are toxic biocides, that kill, reduce or repel insects, weeds, rodents, fungi etc Their mode of action is by attacking enzymes in the pests which may be identical or very similar to systems or enzymes in human beings and therefore, they pose risks to human health and the environment [1]. Pesticides are ubiquitous in the environment which are mostly synthetic. The children's exposure to pesticides and their special susceptibility. Children are not little adults, and may have higher exposures and greater vulnerability at both high and low levels of exposure. Pesticides have numerous beneficial effects. These include crop protection, preservation of food materials and prevention of vectorborne diseases. For example, pesticides may be used in the prevention of malaria, which kills up to 1 million children per year, and for preventing other vector-borne diseases such as leishmaniasis and Japanese encephalitis [1]. Soft drinks

Copyright @ 2020: This is an open-access article distributed under the terms of the Creative Commons Attribution license which permits unrestricted use, distribution, and reproduction in any medium for non commercial use (NonCommercial, or CC-BY-NC) provided the original author and source are credited. 
can be defined as non-alcoholic water-based flavored drinks that can be sweetened or not, acidulated or carbonated and which may contain fruit or fruit juice; their flavor may derive from vegetable extracts or other aromatic substances. They constitute a defined and homogenous range, designated by a generic denomination and utilizing a single common list of additives. They include the beverages which comply with this definition, which utilize these additives and which do not claim to be part of adjacent categories such as fruit juices and nectars, dairy drinks, mineral waters, etc globally; carbonated soft drinks are third most consumed beverages. Per capita annual consumption of carbonated soft drinks is nearly four times the per capita consumption of fruit beverages. (Source: Data from the Beverage Marketing Corporation, as reported by the Canadian Soft Drink Association). Soft drink consumption is growing by around $5 \%$ a year, according to Global Soft drinks 2002. Total volume reached 412,000 million litres in 2001, giving a global per capita consumption of around 67.5 litres per year. The global soft drink industry is highly concentrated, controlled by multinational companies. This research was aimed to evaluate the quantity of these metals and pesticides residues in the commonly consumed soft drink sold within Kazaure town.

\section{Material ANd Methods}

\section{Sampling of soft Drinks}

The Soft drink bottles of different brands were purchased from three locations within kazaure town during the month of April 2017.

\section{Sample Extraction and Preparation Extraction}

Soft drink samples were shaken well and filtered through Whatman filter paper no.1. pH of the samples was checked. $\mathrm{pH}$ of all the samples was adjusted to neutral by using $0.1 \mathrm{~N} \mathrm{NaOH}$. After filtration, 250ml of sample was taken in a $1 \mathrm{~L}$ capacity separatory funnel and $10 \mathrm{ml}$ of saturated sodium chloride solution was added. The sample was partitioned with $50 \mathrm{ml}$ of methylene chloride (thrice) by shaking the separatory funnel in vigorous manner for 2-3 minutes, while pressure intermittently released. The layers were allowed to separate. The three extracts of methylene chloride layers were combined and passed through anhydrous sodium sulfate and concentrated to about 1-2 ml using rotary vacuum evaporator.

\section{Sample Analysis \\ For Organochlorine pesticides}

Organochlorines were analysed by Gas Chromatograph (Thermoquest-Trace GC) with the 63 Ni selective electron capture detector. This detector allows the detection of contaminants at trace level concentrations in the lower ppb range in the presence of a multitude of compounds extracted from the matrix to which the detector does not respond. The capillary column used was DB-1701 [(14\%-Cyanopropyl-phenyl)-methylpolysiloxane (length 30m, ID 0.25 mm and film $0.25 \mathrm{~mm}$ )]. The carrier gas and the makeup gas was nitrogen with a $0.5 \mathrm{ml} / \mathrm{min}$ and $30 \mathrm{ml} / \mathrm{min}$-flow rate respectively employing the split less mode. $2.0 \mathrm{ml}$ of the final extract was injected at a temperature of $2500 \mathrm{C}$. The oven temperature was kept at $1500 \mathrm{C}$ with a hold time of 1 minute, then from $1500 \mathrm{C}$ to $2000 \mathrm{C}$ at a rate of $100 \mathrm{C} / \mathrm{min} u$ te with a hold time of 1 minute and then from $2000 \mathrm{C}$ to $2500 \mathrm{C}$ at a rate of $10 \mathrm{C} /$ minute with a hold time of 1 minute and finally to $2800 \mathrm{C}$ at the rate of $100 \mathrm{C} /$ minute with a hold time of 4 minutes. The total run time was 65 minutes. The detector was maintained at 3000C. Peak identification was performed by the GC software (Chromcard-32bit Version 1.06 October 98) calibration table set up with a relative retention time window of $0.65 \%$.

\section{For Organophosphorus pesticides}

Organophosphorus pesticides were analysed by Gas Chromatograph (Nucon-5765 series equipped with nitrogen phosphorus detector). The capillary column to be use with another GLC capillary column DB-210 [50\% trifluoro propyl polysiloxane, $50 \%$ methyl polysiloxane (length $30 \mathrm{~m}$, ID $0.25 \mathrm{~mm}$ and film $0.25 \mathrm{~mm}$ )]. The carrier gas and the makeup gas was nitrogen with a $2 \mathrm{ml} / \mathrm{min}$ and $30 \mathrm{ml} / \mathrm{min}$-flow rate respectively, hydrogen at $8 \mathrm{ml} / \mathrm{min}$ and air at $80 \mathrm{ml} / \mathrm{min}$ was used for employing the split less mode. $2.0 \mathrm{ml}$ of the final extract was injected at a temperature of $270^{\circ} \mathrm{C}$. The oven temperature was kept at $120^{\circ} \mathrm{C}$ with a hold time of 1 minute, then from $120^{\circ} \mathrm{C}$ to $205^{\circ} \mathrm{C}$ at a rate of $250 \mathrm{C} /$ minute with a hold time of 1 minute and then finally from $2050 \mathrm{C}$ to $2500 \mathrm{C}$ at a rate of $1^{0} \mathrm{C} /$ minute with a hold time of 1 minute. The total run length was at 51.4 minutes. The detector was maintained at $300^{0} \mathrm{C}$. The samples were calibrated (retention time, area count) against standard mixture of known concentration of 13 organophosphorus pesticides. Each peak was characterized by comparing relative retention time with those of standards. Analysis of the blank samples was also included. A laboratory reagent blank of an aliquot of reagent water that was treat as a sample including exposure to all glassware equipment, solvents and reagents that was used, to determine if method analytes or other interferences are present in the laboratory experiment, the reagent or the apparatus. 


\section{Samples Recovery}

A laboratory fortified sample matrix to which known quantities of the method analytes was added in the laboratory and analysed exactly like the sample to determine whether a sample matrix contributed bias to analytical results and to determine that methodology is in control state. Recovery experiment was performed and recovery was about $68 \%-100 \%$ for organochlorines, about $54 \%-102 \%$ for organophosphorus pesticides. The reproducibility of results for all the pesticides was 95 percent and above for all the samples. However, the mean average reading of an individual sample was analyzed in duplicate.

\section{$G C-M S$}

The presence of pesticide residues detected in the samples by GC-ECD and GC-NPD was confirmed by GCMS [Model Finnigan Polaris Q Ion trap GC/MSn with EI ionization (70eV)], in Selective Ion Monitoring (SIM) mode. The sample and standards was injected using a programmable temperature injector (PTV) with a cold solvent split less injection of $2 \mathrm{ml}$. The capillary column DB-1701 $(30 \mathrm{~m} \times 0.25 \mathrm{~mm} \times 0.25 \mathrm{~m})$ was used. The oven temperature was kept at $150^{\circ} \mathrm{C}$ with a hold time of 1 minute, then from $150^{\circ} \mathrm{C}$ to $200^{\circ} \mathrm{C}$ at a rate of $10^{\circ} \mathrm{C} /$ minute with a hold time of 1 minute and then from $200^{\circ} \mathrm{C}$ to $250^{\circ} \mathrm{C}$ at a rate of $1^{\circ} \mathrm{C} /$ minute with a hold time of 1 minute and finally from $250^{\circ} \mathrm{C}$ to $280^{\circ} \mathrm{C}$ at $10^{\circ} \mathrm{C} /$ minute with a hold time of 4 minutes. The carrier gas was helium with a $0.5 \mathrm{ml} / \mathrm{min}$ flow rate employing the split less mode. $2.0 \mathrm{ml}$ of the final extract $(2 \mathrm{ml})$ was injected at a temperature of $275^{\circ} \mathrm{C}$ keeping the ion source at $230^{\circ} \mathrm{C}$; Multiplier: 1100 Volts; AGC: 50, 3 microscan; Default: Tune parameters: Autotune Tune File; Mass Range: 50- 650 $\mathrm{m} / \mathrm{z}$; SIM: Exact Mass +/- $0.5 \mathrm{amu}$.

\section{Metal Analysis}

Twenty-five (25) brands of soft drink samples were randomly selected for analysis and were purchased in April, 2017 in kazaure local Governmet, Jigawa state Nigeria were used in the study. The samples were digested using $96 \%$ of nitric acid to remove organic material by decomposing them into carbon dioxide $\left(\mathrm{CO}_{2}\right) ;\left(\mathrm{CH}_{2}\right) \mathrm{n}+2 \mathrm{HNO}_{3} \rightarrow$ $\mathrm{CO}_{2}+2 \mathrm{NO}+2 \mathrm{H}_{2} \mathrm{O}$ and also to convert the metals present into soluble forms. All chemicals and reagents used are of analytical grade. Nitric acid (GFS Chemicals Inc., Columbus, 69\%) was used to digest the samples for analysis. Deionised water analytical reagent grade (BDH Ltd, Poole, Dorset, UK), Zinc chloride analytical reagent grade (BDH Ltd, Poole, Dorset, UK), analytical reagent grade (BDH Ltd, Poole, Dorset, UK), and Chromium (II) Potassium Sulphate 12 hydrate analytical reagent grade (BDH Ltd, Poole, Dorset, UK) were used to prepare the standard solutions for the calibration plot. Determination of toxic metal ion concentration was carried out using the atomic absorption spectrophotometry (AAS).

\section{Sample digestion for metal Analysis}

Concentrated nitric acid (69\%), $10 \mathrm{ml}$, was added to $25 \mathrm{ml}$ of the sample (soft drink). The mixture was evaporated on a hot plate in a fume cupboard until the brown fumes disappears leaving white fumes. $50 \mathrm{ml}$ of distilled water was added and this was concentrated by evaporation on a hot plate to $25 \mathrm{ml}$. Subsequently, additional $25 \mathrm{ml}$ of distilled water was added to make up to $50 \mathrm{ml}$. This was then filtered and ready for AAS analysis [2].

\section{Standard metal ion preparation}

The calibration plot method described in the British pharmacopoeia, 2005, was adopted for the analysis [3]. A stock standard solution, $1000 \mathrm{ppm}$, of the metal ion was prepared by dividing the molar mass of the compound containing the element by the molar mass of the element. The weight obtained was equivalent to $1.0 \mathrm{~g}$ of the metal ion. This weight (which is equivalent to $1.0 \mathrm{~g}$ of the metal) was dissolved in $1000 \mathrm{ml}$ to give $1000 \mathrm{ppm}$. A working solution of $100 \mathrm{ppm}$ was prepared from the stock solution. Serial dilutions were prepared from the working solution. The absorbance of these solutions was obtained using the AAS. The calibration graph was plotted and the regression equation was obtained. Deionised water was used as control.

\section{Sample analysis}

The calibration plot method was used using the AAS equipped with appropriate filter for each metal ion. The concentration of the digested soft drink samples was derived from the regression equation and the samples were analyzed in duplicates.

\section{Calculations} were obtained.

All calculations were perform as described in USEPA method and the amount of pesticide residues in samples 


\section{RESUlT AND DisCUSSION}

\section{Determination of Organochlorine Pesticides in soft drinks}

A total of 25 soft drinks samples of different brands were tested for 10 organochlorine pesticides and 5 organophosphorus pesticides. The average concentration of all the ten (10) organochlorines pesticides evaluated were $0.11,0.00,0.22$ and $0.26 \mu \mathrm{g} / \mathrm{kg}$ for $\alpha-\mathrm{HCH}, \gamma-\mathrm{HCH}, \delta-\mathrm{HCH}$ and heptachlor respectively while $\beta-\mathrm{HCH}$, DDT, Aldrin, Dieldrin Endosulfan and chlordane were not detected in all the brand of the soft drinks evaluated. The overall average of all the organochlorines pesticdes were found to be $3.71 \mu \mathrm{g} / \mathrm{kg}$. $\alpha-\mathrm{HCH}$ concentration was found in $8 \%$ of the 25 soft drinks analysed range from $0.13-1.62 \mu \mathrm{g} / \mathrm{kg}$. The concentration of $\gamma-\mathrm{HCH}$ was not detected in the $25 \mathrm{samples}$ of soft drinks, while $\delta-\mathrm{HCH}$ and heptachlor concentration were varied from $0.10-0.84 \mu \mathrm{g} / \mathrm{kg}$ found in $68 \%$ and $0.12-1.43$ in $64 \%$ of 25 samples of soft drinks respectively. DDT, Aldrin, Dieldrin, Endosulfan and Chlordane were not detected in any of the samples (Table 1).

All isomers of $\mathrm{HCH}$ are stored in fats; the gamma isomer of $\mathrm{HCH}$ (Lindane) which was found to be in $0 \% \%$ of the samples analysed is stored at much larger rates than the other isomers, which are more readily metabolized and eliminated. The alpha, beta and sigma $\mathrm{HCH}$ were found in $8 \%, 0.0 \%$ and $68 \%$ respectively. Gamma isomer (Lindane) is absorbed through respiratory, digestive or cutaneous routes and accumulates in fat tissues. It damages human liver, kidney, neural and immune systems and induces birth defects, cancer and death. Chronic administration results in endocrine disruption in birds as well as in mammals [4]. This result is contrary to the report of [5] whose reported higher level of gamma HCH in soft drinks. The toxic effect of heptachlor is mainly through residues in food. Heptachlor is a persistent pesticide and bioaccumulation and biomagnification occur and bioconcentration factors of 200 - 37000X have been reported from water into hydro-biota. Heptachlor has been shown to be toxic for aquatic life, but its toxicity is highly species variable. Heptachlor is readily absorbed following ingestion and skin contact and is transported throughout the body. Heptachlor epoxide, the most persistent metabolite, is rapidly formed and can be found in the body, mainly in adipose tissue. The toxicity of heptachlor epoxide is similar to that of heptachlor. According to the classification [6], the acute toxicity of heptachlor is moderate (acute oral LD50 for the rat $40-162 \mathrm{mg} / \mathrm{kg}$ ). Toxic symptoms are related to hyper excitability of the central nervous system and include tremors and convulsions. Death may follow respiratory failure. At non-lethal acute exposures, heptachlor is hepatotoxic.

Table-1: Level of Some Organochlorine Pesticide in Soft Drinks

\begin{tabular}{|c|c|c|c|c|c|c|c|c|c|c|c|}
\hline S/NO & $\begin{array}{c}\text { Alpha( } \\
\alpha) \\
\text { HCH } \\
(\mu \mathrm{g} / \mathrm{kg}) \\
\end{array}$ & $\begin{array}{c}\text { Beta } \\
(\beta) \\
\text { HCH } \\
(\mu \mathrm{g} / \mathrm{kg})\end{array}$ & $\begin{array}{c}\text { Sigma } \\
(\gamma)- \\
\text { HCH } \\
(\mu \mathrm{g} / \mathrm{kg})\end{array}$ & $\begin{array}{l}\text { Delta }(\delta \\
)-H C H \\
(\mu \mathrm{g} / \mathrm{kg})\end{array}$ & $\begin{array}{c}\text { Heptach } \\
\operatorname{lor}(\mu \mathrm{g} / \mathrm{k} \\
\mathrm{g})\end{array}$ & $\begin{array}{l}\text { DDT } \\
(\mu \mathrm{g} / \mathrm{kg})\end{array}$ & $\begin{array}{l}\text { Aldrin } \\
(\mu \mathrm{g} / \mathrm{kg})\end{array}$ & $\begin{array}{l}\text { Dieldrin } \\
(\mu \mathrm{g} / \mathrm{kg})\end{array}$ & $\begin{array}{c}\text { Endosulfa } \\
\mathrm{n}(\mu \mathrm{g} / \mathrm{kg})\end{array}$ & $\begin{array}{c}\text { Chlordan } \\
\text { e }(\mu \mathrm{g} / \mathrm{kg})\end{array}$ & $\begin{array}{c}\text { Total } \\
\text { Organochlori } \\
\text { nes }(\mu \mathrm{g} / \mathrm{kg})\end{array}$ \\
\hline SD1 & 0.00 & 0.00 & 0.00 & 0.22 & 0.27 & 0.00 & 0.00 & 0.00 & 0.00 & 0.00 & 3.02 \\
\hline SD2 & 0.00 & 0.00 & 0.00 & 0.11 & 0.29 & 0.00 & 0.00 & 0.00 & 0.00 & 0.00 & 4.84 \\
\hline SD3 & 0.00 & 0.00 & 0.00 & 0.14 & 0.59 & 0.00 & 0.00 & 0.00 & 0.00 & 0.00 & 3.50 \\
\hline SD4 & 0.00 & 0.00 & 0.00 & 0.21 & 0.43 & 0.00 & 0.00 & 0.00 & 0.00 & 0.00 & 4.89 \\
\hline SD5 & 0.00 & 0.00 & 0.00 & 0.11 & 0.50 & 0.00 & 0.00 & 0.00 & 0.00 & 0.00 & 2.28 \\
\hline SD6 & 0.00 & 0.00 & 0.00 & 0.00 & 1.13 & 0.00 & 0.00 & 0.00 & 0.00 & 0.00 & 6.10 \\
\hline SD7 & 0.00 & 0.00 & 0.00 & 0.00 & 0.12 & 0.00 & 0.00 & 0.00 & 0.00 & 0.00 & 4.02 \\
\hline SD8 & 0.00 & 0.00 & 0.00 & 0.23 & 0.15 & 0.00 & 0.00 & 0.00 & 0.00 & 0.00 & 0.38 \\
\hline SD9 & 0.00 & 0.00 & 0.00 & 0.21 & 0.09 & 0.00 & 0.00 & 0.00 & 0.00 & 0.00 & 2.12 \\
\hline SD10 & 0.00 & 0.00 & 0.00 & 0.10 & 0.14 & 0.00 & 0.00 & 0.00 & 0.00 & 0.00 & 3.48 \\
\hline SD11 & 0.00 & 0.00 & 0.00 & 0.00 & 0.27 & 0.00 & 0.00 & 0.00 & 0.00 & 0.00 & 2.79 \\
\hline SD12 & 0.13 & 0.00 & 0.00 & 0.31 & 0.00 & 0.00 & 0.00 & 0.00 & 0.00 & 0.00 & 4.22 \\
\hline SD13 & 0.00 & 0.00 & 0.00 & 0.15 & 0.00 & 0.00 & 0.00 & 0.00 & 0.00 & 0.00 & 3.55 \\
\hline SD14 & 0.00 & 0.00 & 0.00 & 0.56 & 0.27 & 0.00 & 0.00 & 0.00 & 0.00 & 0.00 & 3.36 \\
\hline SD15 & 0.00 & 0.00 & 0.00 & 0.34 & 0.00 & 0.00 & 0.00 & 0.00 & 0.00 & 0.00 & 0.34 \\
\hline SD16 & 0.00 & 0.00 & 0.00 & 0.00 & 0.00 & 0.00 & 0.00 & 0.00 & 0.00 & 0.00 & 4.27 \\
\hline SD17 & 0.00 & 0.00 & 0.00 & 0.84 & 0.00 & 0.00 & 0.00 & 0.00 & 0.00 & 0.00 & 3.61 \\
\hline SD18 & 0.00 & 0.00 & 0.00 & 0.00 & 0.00 & 0.00 & 0.00 & 0.00 & 0.00 & 0.00 & 5.10 \\
\hline SD19 & 1.62 & 0.00 & 0.00 & 0.64 & 0.00 & 0.00 & 0.00 & 0.00 & 0.00 & 0.00 & 6.05 \\
\hline SD20 & 0.00 & 0.00 & 0.00 & 0.75 & 0.00 & 0.00 & 0.00 & 0.00 & 0.00 & 0.00 & 0.75 \\
\hline SD21 & 0.99 & 0.00 & 0.00 & 0.23 & 0.00 & 0.00 & 0.00 & 0.00 & 0.00 & 0.00 & 4.24 \\
\hline SD22 & 0.00 & 0.00 & 0.00 & 0.00 & 0.41 & 0.00 & 0.00 & 0.00 & 0.00 & 0.00 & 5.37 \\
\hline SD23 & 0.00 & 0.00 & 0.00 & 0.00 & 1.43 & 0.00 & 0.00 & 0.00 & 0.00 & 0.00 & 6.47 \\
\hline SD24 & 0.00 & 0.00 & 0.00 & 0.23 & 0.12 & 0.00 & 0.00 & 0.00 & 0.00 & 0.00 & 5.55 \\
\hline SD25 & 0.00 & 0.00 & 0.00 & 0.00 & 0.25 & 0.00 & 0.00 & 0.00 & 0.00 & 0.00 & 2.48 \\
\hline Average & 0.11 & 0.00 & 0.00 & 0.22 & 0.26 & 0.00 & 0.00 & 0.00 & 0.00 & 0.00 & 3.71 \\
\hline
\end{tabular}

\section{Level of Organophosphorus Pesticides in soft drinks}

The concentration of organophosphorous pesticide were quantified in all the 25 samples of soft drink selected, $0.74 \mu \mathrm{g} / \mathrm{kg}$ and $0.17 \mu \mathrm{g} / \mathrm{kg}$ were found as the average concentration of Chlorpyrifos and malathion respectively. While the average concentration of the total organophosphorous pesticides obtained was $0.89 \mu \mathrm{g} / \mathrm{kg}$. Chlorpyrifos and 
malathion were found in 48 and $44 \%$ of the 25 samples which range from 0.17 to 2.89 and 0.13 to $1.11 \mu \mathrm{g} / \mathrm{kg}$ respectively (Table 2). The parathion, merphos and tricresylphosphate were not detected in all the 25 soft drink tested.

Chlorpyrifos, is one of the most widely used organophosphorus pesticide and has been reported to be a developmental neurotoxicant specifically targeting the immature brain [8,9]. Foetal and childhood exposure to chlorpyrifos has raised concerns about developmental neurotoxicity. Exposure to chlorpyrifos resulted in adverse effects on brain cell development and cholinergic biomarkers. Neonatal rats were found to be more sensitive to chlorpyrifos than the fetal rats and animals exposed prenatally developed behavioral deficits in adolescence and adulthood[10]. Studies carried out to evaluate potential toxicological effects of chlorpyrifos in rats showed that repeated exposure to sub threshold dozes of chlorpyrifos may lead to growth retardation, behavioral abnormalities and muscle weakness [11]. Chronic exposure to chlorpyrifos has been shown to cause immunological change [12]. While Malathion, a known cholinesterase inhibitor, leads to the hydrolysis of body choline esters, including acetylcholine at cholinergic receptors. It has been shown to induce changes in the epithelium of rat mammary glands, influencing the process of carcinogenesis; such alterations occur at the level of nervous system by increasing the cholinergic stimulation [13]. Malathion induces alterations in actin cytoskeleton and in cell adhesion of cultured breast carcinoma cells [14]. It has been reported to induce a slight increase in the incidence of chromosomal aberrations in bone marrow cells of rats exposed in vivo [15]. Malathion caused a significant increase in sister chromatid exchange in human foetal lung fibroplasts after a single dose of $40 \mathrm{~kg} / \mathrm{l}$ or a double dose of $20 \mathrm{~kg} / 1$ [16].

Table-2: Level of Some Organophosphate Pesticide In Soft Drinks

\begin{tabular}{|c|c|c|c|c|c|c|}
\hline S/NO & $\begin{array}{c}\text { Chlorpyrifos } \\
(\mu \mathrm{g} / \mathrm{kg})\end{array}$ & $\begin{array}{c}\text { Malathion } \\
(\mu \mathrm{g} / \mathrm{kg})\end{array}$ & $\begin{array}{c}\text { Parathion } \\
(\mu \mathrm{g} / \mathrm{kg})\end{array}$ & $\begin{array}{c}\text { Merphos } \\
(\mu \mathrm{g} / \mathrm{kg})\end{array}$ & $\begin{array}{c}\text { Tricresyl } \\
\text { phosphate } \\
(\mu \mathrm{g} / \mathrm{kg})\end{array}$ & $\begin{array}{c}\text { Total } \\
\begin{array}{c}\text { Organophosphates } \\
(\mu \mathrm{g} / \mathrm{kg})\end{array}\end{array}$ \\
\hline SD1 & 0.00 & 0.60 & 0.00 & 0.00 & 0.00 & 0.60 \\
\hline SD2 & 0.77 & 0.00 & 0.00 & 0.00 & 0.00 & 0.77 \\
\hline SD3 & 1.62 & 1.11 & 0.00 & 0.00 & 0.00 & 2.72 \\
\hline SD4 & 2.49 & 0.00 & 0.00 & 0.00 & 0.00 & 2.49 \\
\hline SD5 & 2.15 & 0.00 & 0.00 & 0.00 & 0.00 & 2.15 \\
\hline SD6 & 0.00 & 0.00 & 0.00 & 0.00 & 0.00 & 0.00 \\
\hline SD7 & 0.00 & 0.00 & 0.00 & 0.00 & 0.00 & 0.00 \\
\hline SD8 & 0.00 & 0.00 & 0.00 & 0.00 & 0.00 & 0.00 \\
\hline SD9 & 0.00 & 0.60 & 0.00 & 0.00 & 0.00 & 0.60 \\
\hline SD10 & 0.00 & 0.00 & 0.00 & 0.00 & 0.00 & 0.00 \\
\hline SD11 & 0.00 & 0.41 & 0.00 & 0.00 & 0.00 & 0.41 \\
\hline SD12 & 2.00 & 0.00 & 0.00 & 0.00 & 0.00 & 2.00 \\
\hline SD13 & 0.24 & 0.13 & 0.00 & 0.00 & 0.00 & 0.37 \\
\hline SD14 & 0.00 & 0.00 & 0.00 & 0.00 & 0.00 & 0.00 \\
\hline SD15 & 0.00 & 0.00 & 0.00 & 0.00 & 0.00 & 0.00 \\
\hline SD16 & 0.35 & 0.25 & 0.00 & 0.00 & 0.00 & 0.60 \\
\hline SD17 & 0.00 & 0.36 & 0.00 & 0.00 & 0.00 & 0.36 \\
\hline SD18 & 2.56 & 0.36 & 0.00 & 0.00 & 0.00 & 2.92 \\
\hline SD19 & 0.00 & 0.00 & 0.00 & 0.00 & 0.00 & 0.00 \\
\hline SD20 & 2.89 & 0.15 & 0.00 & 0.00 & 0.00 & 3.04 \\
\hline SD21 & 0.00 & 0.15 & 0.00 & 0.00 & 0.00 & 0.15 \\
\hline SD22 & 0.00 & 0.22 & 0.00 & 0.00 & 0.00 & 0.22 \\
\hline SD23 & 0.17 & 0.00 & 0.00 & 0.00 & 0.00 & 0.17 \\
\hline SD24 & 2.58 & 0.00 & 0.00 & 0.00 & 0.00 & 2.58 \\
\hline SD25 & 0.20 & 0.00 & 0.00 & 0.00 & 0.00 & 0.20 \\
\hline Average & 0.72 & 0.17 & 0.00 & 0.00 & 0.00 & 0.89 \\
\hline
\end{tabular}

\section{Level of Metal Residue in Commercially Sold Soft Drinks}

The concentrations of the metals such as cupper $(\mathrm{Cu})$, Chromium $(\mathrm{Cr})$, cadmium $(\mathrm{Cd})$, iron $(\mathrm{Fe}), \mathrm{lead}(\mathrm{Pb}), \mathrm{zinc}$ $(\mathrm{Zn})$ and nickel $(\mathrm{Ni})$ were evaluated on the 25 samples of soft drink commonly sold in Kazaure Local Government of Jigawa State. The concentration level of $\mathrm{Cu}$ was found to be in $68 \%$ of the 25 samples analyzed ranging from 0.11 to $0.64 \mathrm{mg} / \mathrm{l}$, the lowest value was in SD12 while the highest was found in SD6. However, all the values obtained were within the permissible recommended level (PRL) of $2.00 \mathrm{mg} / \mathrm{l}$ set by WHO and USEPA. The Cr level was found in $56 \%$ of the 25 soft drink analysed ranged from 0.01 to $0.08 \mathrm{mg} / \mathrm{l}$ the lowest value was found in SD7,19,21 while the highest was in SD18, 16\% of the samples contained Cr above the RPL by WHO and USEPA. Cadmiun concentration levels was found in $36 \%$ of the soft drinks analysed which range from 0.003 to $0.02 \mathrm{mg} / \mathrm{l}$, the lowest value as found in SD3 while the highest was in SD7 and SD20 all the 25 samples were within the permissible recommended level. The levels of Fe, $\mathrm{Pb}, \mathrm{Zn}$ and $\mathrm{Ni}$ of 25 soft drinks were found to be at 88, 40, 80 and $24 \%$ ranged from $0.10-0.99,0.01-0.05,0.05-1.01$ and 
0.01-0.49 respectively. Zinc level was found all within the PRL while $\mathrm{Fe}, \mathrm{Pb}$, and $\mathrm{Ni}$ were found to be $48 \%, 12 \%$ and $12 \%$ above the permissible recommended levels respectively (Table 3 ).

Copper is essential for body functions and does not courses any harm if present within the recommended level as obtained in this study. However, Copper toxicity may result from eating acid foods cooked in uncoated copper cookware or from exposure to excess copper in drinking water due to environmental contaminant or from the sources of water being used for the production of soft drink or any other beverages [17]. The acute symptoms of exposure to excess copper which can be by ingestion may include vomiting, hematemesis, coma, jaundice and gastrointestinal distress etc [17]. Long term exposure to high amounts of copper causes liver and kidneys disease. Some effects stated here may be expected from ingestion of soft drinks with high copper content. This is contrary to what was obtained in this study as all the 25 samples of soft drink evaluated were within the permissible recommended level as stated by WHO, 2018. The water used for soft drinks production could be a source of $\mathrm{Cu}$ in the beverages. Common sources of Copper contaminant in water supplies are from corrosion of plumbing [18].

The concentration of chromium level was found in $56 \%$ soft drink samples analysed, in which $16 \%$ were above the PRL of $(0.05 \mathrm{mg} / \mathrm{L})$ (Table3). The $16 \%$ levels obtained in this study is higher than the chromium levels reported by [19]. Chromium is essential for the maintenance of protein, lipid and glucose metabolism. Chromium supplementation with $1000 \mu \mathrm{g}$ of chromium can reduced the level of glycosylated haemoglobin by $2 \%$ in type 2 diabetes mellitus patients. It is important to note that patients with type 2 diabetes mellitus may be at risk of hypoglycaemic consequent if chromium supplements used as self-medication. Even though chromium intake as essential elements for maintenance of wellbeing consumption of soft drinks may be the causes of higher levels of chromium together with other beverages. This may result in large accumulation of chromium in the body may have result in potentially fatal, effects in the respiratory, cardiovascular, gastrointestinal, hepatic, renal, and neurological systems [20].

The concentration of cadmium level in the 25 soft drinks analysed ranged from 0.003 to 0.02 . Found in $36 \%$ of the samples and it does not exceed the permissible limits of $0.005 \mathrm{mg} / \mathrm{l}$ set by WHO and USEPA. Cadmium levels has been found to potentially cause nausea, vomiting, diarrhea, muscle cramps, salivation, sensory disturbances, liver injury, convulsions, shock and renal failure in a small quantity. Also Long-term exposure to have the potential to cause kidney, liver and bone damage. Cadmium is carcinogenic element [21]. Corrosion of galvanized pipes, erosion of natural deposits, discharge from metal refineries, runoff from waste batteries and paint are all sources of $\mathrm{Cd}$ in water from where it may have been introduced into the soft drinks. Therefore, $\mathrm{Cd}$ above safe limits in soft drinks is an issue of great risk to the consumers due to it higher effects on the human health. Similar Studies on the levels of metals in Nigerian beverages have been previously reported; some of the reported data are higher than what obtained in this study. Maduabuchi et al [22] reported Cd levels as $0.002-0.0073 \mathrm{mg} / \mathrm{l}$ in canned drinks and $0.092 \mathrm{mg} / \mathrm{l}$ in non-canned drinks. The cadmium levels obtained in this study fall within this range.

The levels of $\mathrm{Fe}, \mathrm{Pb}, \mathrm{Zn}$ and $\mathrm{Ni}$ of 25 soft drinks were found to be at 88, 40, 80 and $24 \%$ ranged from 0.10 $0.99,0.01-0.05,0.05-1.01$ and $0.01-0.49$ respectively. Zinc level was found all within the PRL while Fe, Pb, and Ni were found to be $48 \%, 12 \%$ and $12 \%$ above the permissible recommended levels respectively (Table 3 ). Fe is being classified as secondary contaminant and it may have no deleterious effects to health. Only effects related to aesthetic issues would be expected; Fe levels above the PRL of USEPA $0.3 \mathrm{mg} / \mathrm{l}$ in water may lead to bad taste, teeth staining and formation of sediment and yellow, red, and orange films [23]. Iron toxicity is usually associated with a genetic disorder [18]. The high concentration of iron found in some of the studied samples may be attributed to poor water treatment and bad production processes. The source of iron may be related from metal corrosion during distribution in the pipes [24].

Lead is known to have acute and chronic effects on human health. It is a multi-organ system toxicant that can cause neurological, cardiovascular, renal, gastrointestinal, haematological and reproductive effects [20]. Pb is considered the most ubiquitous of toxic metals in drinking water; it can leach from water pipes and soldered joints which deliver water during soft drink production. The $12 \%$ levels of lead in soft drink obtained in this study is contrary to the Adepoju-Bello et al. [25] whose reported no any amount of lead obtained in the soft drink. However, this study revealed lower concentrations when compared with Engwa [26] reports. Similarly, study with the report report of Garba et al, [22] which presented lower concentration of the lead in some soft drinks evaluated. The lowest concentration for Zinc found in SD 23 was $0.05 \mathrm{mg} / \mathrm{l}$ while the highest concentration $1.01 \mathrm{mg} / \mathrm{l}$ obtained in SD20. The maximum contaminant level for Zn stipulated for drinking water is $5 \mathrm{mg} / \mathrm{l}$. When Zinc level of water is higher that the PRL the water may have a metallic bitter taste and in which $2540 \mathrm{mg} / \mathrm{l}$ concentration may result to vomiting and other stomach discomfort the levels of Zinc contents in 25 samples of the soft drink analyzed were below $5.00 \mathrm{mg} / \mathrm{l}$ limit. This indicated that the result obtained showed no any effect related to the zinc is expected from the samples analysed, this is in agreement with this study. 
Table-3: Level of Metal Residue in Commercially Sold Soft Drinks

\begin{tabular}{|c|c|c|c|c|c|c|c|}
\hline SAMPLES & $\mathrm{Cu}(\mathrm{mg} / \mathrm{l})$ & $\mathrm{Cr}(\mathrm{mg} / \mathrm{l})$ & $\mathrm{Cd}(\mathrm{mg} / \mathrm{l})$ & $\mathrm{Fe}(\mathrm{mg} / \mathrm{l})$ & $\mathrm{Pb}(\mathrm{mg} / \mathrm{l})$ & Zn(mg/l) & $\mathrm{Ni}(\mathrm{mg} / \mathrm{l})$ \\
\hline SD1 & $0.18 \pm 0.06$ & $0.03 \pm 0.00$ & $0.01 \pm 0.00$ & $0.71 \pm 0.02$ & $0.02 \pm 0.01$ & $0.18 \pm 0.01$ & ND \\
\hline SD2 & $0.51 \pm 0.00$ & $0.05 \pm 0.01$ & ND & $0.20 \pm 0.01$ & $0.01 \pm 0.00$ & $0.91 \pm 0.10$ & ND \\
\hline SD3 & $0.38 \pm 0.02$ & $0.06 \pm 0.01$ & $0.003 \pm 0.00$ & $0.67 \pm 0.10$ & $0.01 \pm 0.00$ & $0.15 \pm 0.02$ & ND \\
\hline SD4 & $0.55 \pm 0.01$ & ND & ND & $0.99 \pm 0.04$ & ND & $0.51 \pm 0.06$ & ND \\
\hline SD5 & $0.20 \pm 0.01$ & $0.02 \pm 0.00$ & $0.005 \pm 0.00$ & $0.53 \pm 0.11$ & ND & $0.12 \pm 0.02$ & ND \\
\hline SD6 & $0.64 \pm 0.02$ & ND & ND & $0.17 \pm 0.01$ & ND & $0.78 \pm 0.10$ & ND \\
\hline SD7 & $0.30 \pm 0.08$ & $0.01 \pm 0.01$ & $0.02 \pm 0.01$ & $0.79 \pm 0.02$ & ND & $0.25 \pm 0.05$ & ND \\
\hline SD8 & $0.54 \pm 0.15$ & $0.04 \pm 0.00$ & $0.01 \pm 0.00$ & $0.64 \pm 0.04$ & ND & $0.47 \pm 0.04$ & ND \\
\hline SD9 & $0.08 \pm 0.02$ & $0.02 \pm 0.00$ & ND & $0.17 \pm 0.03$ & ND & $0.70 \pm 0.03$ & $0.49 \pm 0.02$ \\
\hline SD10 & $0.09 \pm 0.03$ & $0.04 \pm 0.01$ & ND & $0.81 \pm 0.12$ & $0.05 \pm 0.02$ & $0.41 \pm 0.03$ & ND \\
\hline SD11 & $0.36 \pm 0.01$ & ND & ND & $0.35 \pm 0.04$ & ND & $0.21 \pm 0.01$ & $0.01 \pm 0.00$ \\
\hline SD12 & $0.11 \pm 0.01$ & $0.07 \pm 0.03$ & ND & $0.10 \pm 0.03$ & ND & $0.42 \pm 0.06$ & $0.21 \pm 0.02$ \\
\hline SD13 & $0.20 \pm 0.04$ & $0.06 \pm 0.02$ & ND & $0.72 \pm 0.40$ & $0.01 \pm 0.00$ & $0.99 \pm 0.02$ & ND \\
\hline SD14 & $0.34 \pm 0.02$ & ND & $0.01 \pm 0.00$ & $0.23 \pm 0.10$ & ND & $0.82 \pm 0.00$ & ND \\
\hline SD15 & $0.23 \pm 0.01$ & ND & ND & $0.79 \pm 0.02$ & $0.02 \pm 0.01$ & $0.52 \pm 0.02$ & $0.17 \pm 0.02$ \\
\hline SD16 & $0.07 \pm 0.01$ & $0.04 \pm 0.01$ & ND & $0.87 \pm 0.20$ & ND & $0.85 \pm 0.01$ & ND \\
\hline SD17 & $0.32 \pm 0.06$ & ND & $0.01 \pm 0.00$ & $0.24 \pm 0.15$ & $0.01 \pm 0.01$ & $0.02 \pm 0.00$ & ND \\
\hline SD18 & $0.58 \pm 0.03$ & $0.08 \pm 0.02$ & ND & $0.21 \pm 1.20$ & ND & $0.92 \pm 0.04$ & ND \\
\hline SD19 & $0.15 \pm 0.00$ & $0.01 \pm 0.00$ & ND & $0.89 \pm 0.45$ & ND & $0.42 \pm 0.10$ & $0.01 \pm 0.00$ \\
\hline SD20 & $0.38 \pm 0.04$ & ND & $0.02 \pm 0.01$ & $0.19 \pm 0.03$ & $0.01 \pm 0.01$ & $1.01 \pm 0.02$ & ND \\
\hline SD21 & $0.43 \pm 0.02$ & $0.01 \pm 0.00$ & ND & $0.76 \pm 0.05$ & ND & $0.66 \pm 0.05$ & $0.01 \pm 0.00$ \\
\hline SD22 & $0.22 \pm 0.02$ & ND & $0.01 \pm 0.01$ & $0.23 \pm 0.00$ & $0.01 \pm 0.01$ & $0.08 \pm 0.15$ & ND \\
\hline SD23 & $0.17 \pm 0.04$ & ND & ND & $0.22 \pm 0.80$ & ND & $0.05 \pm 0.02$ & ND \\
\hline SD24 & $0.22 \pm 0.11$ & ND & ND & $0.12 \pm 0.02$ & ND & $0.11 \pm 0.04$ & ND \\
\hline SD25 & $0.13 \pm 0.02$ & ND & ND & $0.12 \pm 0.10$ & $0.01 \pm 0.00$ & $0.13 \pm 0.01$ & ND \\
\hline $\begin{array}{c}\text { Average } \\
\end{array}$ & 0.30 & 0.02 & 0.004 & 0.47 & 0.006 & 0.50 & 0.04 \\
\hline RPL LEVEL WHO/USEPA 2018 & 2.00 & 0.05 & 0.005 & 0.1 & 0.01 & 5.00 & 0.02 \\
\hline
\end{tabular}

Result are presented in triplicate as mean \pm standard deviation

\section{Conclusion}

The total of 15 pesticides residue was analyzed in the 25 samples of different brands of soft drink. The result reveals that Out of the 10 organochlorine pesticides only 4 pesticides and 2 out of 5 organophosphorus pesticides present in the soft drink samples analyzed. Soft drink generally can be served as source of important elements for human health and development but can be as a source of other substance like pesticide and some metals which can be toxic to human.

\section{RECOMMENDATIONS}

- $\quad$ Based on this finding the soft drinks producers should employ good water treatment procedures for human safety.

- Quality control measures should be adopted in order for the safety of their products.

- Other extra care should also be taken by the manufacturers to avoid introducing metals from the industrial processes.

- The equipment used, packing materials and industrial emissions should be monitored regularly.

- Regulatory bodies such as NAFDAC, SON, WHO in the country should carry out regular monitoring of pesticides and metal levels drinks aimed to safe guard public health.

\section{ACKNOWLEDGEMENT}

The authors wish to acknowledge the support of Tertiary Education Trust fund (TETFUND) Nigeria and Hussaini Adamu Federal Polytechnic Kazaure, Jigawa State. Nigeria for sponsoring the Research under Institutional Based Research Grant (TETFUND/DESS/POLY/KZR/IBR/2017).

\section{CONFLICT OF INTEREST}

The authors declared no any conflict of interest.

\section{REFERENCES}

1. Rhorer. (2011). Transfer efficiencies of pesticides from household flooring surfaces to food. J Exp Anal Environ Epidem, 13:454.

2. Kleefstra, N., Bilo, H.J., Bakker, S.J., Houweiling, S.T. (2004). Chromium and insulin resistance. Med. Tildschr Geneeskd, 148: 217-220.

3. Levine, R. (1991). Recognized and possible effects of pesticides in humans. In: Hayes WJ Jr, Laws ER Jr, eds. Handbook of pesticide toxicology. Vol 1. General principles. San Diego: Academic Press: 275-360 
4. Pages, N., Sauvet, M.P., Bouvet, S., Goudey-Perriere, F. (2002). Reproductive toxicity of Lindane, J Soc Biol. 196(4):325-38

5. Sauviat, M.P., Pages, N. (2002). Cardiotoxicity of lindane, a gamma isomer of hexachlorocyclohexane. J Soc Biol, 196(4):339-48

6. Farag, A.T., El, Okazy., A.M., E.1., Aswed, A.F. (2003). Developmental toxicity study of chlorpyrifos in rats. Reprod Toxicol March-April; 17(2):203-8

7. Fenske, R. (2000). Biologically based pesticide dose estimates for children in an agricultural community. Environ Health Perspect 2000, 108:515Barone S, Das KP, Lassiter TL, White LD (2000) Vulnerable process of nervous system development. A review of markers and methods. Neurotoxicology, 21: 15-36.

8. Pope, C.N. (1999). Organophosphorus pesticides: Do they all have the same mechanism of toxicity? J. Toxicol Environ Health, 2: 161-181

9. Qio, D., Seidler, F.J., Tate, C.A., Cousins, M.M., Slotkin, T.A. (2003). Fetal chlorpyrifos exposure: adverse effects on brain cell development and cholinergic biomarkers emerge postnatally and continue into adolescence and adulthood, April, 111(4):536-44).

10. Terry, A.V Jr., Stone, J.D. (2003). Repeated exposures to subthreshold dozes of chlorpyrifos in rats: hippocampal damage, impaired axonal transport, and deficits in spatial learning. J. Pharmacol Exp Ther. Apr; 305(1):375-84.

11. Thrasher, J.D., Heuser, G., Broughton, A. (2002). Immunological abnormalities in humans chronically exposed to chlorpoyrifos. Arch Environ Health, May-Jun, 57(3):181-7

12. Vladimir, T., Valery, R., \& Lorenzo, T. (2002). Dichlorodiphenyl trichloroethane (DDT): Ubiquity, persistence and risks. Env. Health Perspectives, 110(2): 125-128.

13. Cabello, G., Galaz, S., Botella, L., Calaf, G., Pacheco, M., Stockert, J.C., Villanueva, A., Canete, M., Juarranz, A. (2003). The pesticide Malathion induces alterations in actin cytoskeleton and in cell adhesion of cultured breast carcinoma cells. Int J Oncol. Sep, 23(3): 697-704.

14. Kawachi, T., Yahagi, T., Kada, T., Tazima, Y., Ishadate, M., Sasaki, M., \& Sugiyama, T. (1980). Cooperative program on short term assays for carcinogenecity in Japan. IARC Sci. Publi, 27:323

15. Nicholas, A.H.Y., Vienne, M., \& Van, den, Berghe, H. (1979). Induction of sister chromatid exchanges in cultural human cells by an organophosphorus insecticide: Malathion. Mutat Res, 67: 167

16. Klassen, C.D. (2000). Casarett \& Doull's Toxicology, The Basic Science of Poisons, Fifth Edition, McGraw-Hill, New York, 715.

17. Kutsky, R.J. (1981). Handbook of Vitamins, Minerals and Hormones,Second Edition, Van Nostrand Reinhold Co. New York.

18. Garcia, E.M., Cabrera, C., Sanchez, J., Lorenzo, M., Lopez, M.C. (1999). Chromium levels in public water, fruit juices and soft drinks: influence on dietary intake. Sci. Total Environ. 241: 143-150.

19. International Programme on Chemical Safety (IPCS). (2006). Inorganic chromium (VI) compounds. Draft, Concise International Chemical Assessment Document. WHO, Geneva.

20. Rubı, C., Hardisson, A., Reguera, J.I., Revert, C., Lafuente, M.A., \& Gonzalez-Iglesias, T. (2006). "Cadmium dietary intake in the Canary Islands, Spain”, Environmental Research, 100: 123-129

21. Maduabuchi, J.M.U., Nzegwu, C.N., Adigba, E.O., Aloke, R.U., Ezomıke, C.N., Okocha C.E., Obi, E. \& Orisakwe, O.E. (2006). "Lead and cadmium exposures from canned and non-canned beverages in Nigeria: A public health concern". Science Total of Environment, 366, 621-626.

22. Wu, J, Laird, D.A. (2003). Abiotic transformation of chlorpyrifos to chlorpyrifos -oxon in chlorinated wate., Environ Toxicol Chem, Feb; 22(2):261-4

23. Garba, Z. N., Ugbaje, C., Abdullahi, A. K., \& Garba, N.N. (2013). "Chromium, nickel and zinc levels from canned and noncanned beverages in zaria, kaduna state, nigeria” Bayero Journal Of Pure And Applied Sciences, 6(1), 174178

24. Gedge, G. (1992). Corrosion of Cast Iron in Potable Water Service. Proc. corrosion and related aspects of materials for Potable water supplies, Proceedings of the institute of materials conference. London, UK,

25. Adepoju-Bello, A.A., Oguntibeju, O.O., Onuegbu, M.T., Ayoola, G.A.A., \& Coker, H.A.B. (2012). Analysis of selected metallic impurities in soft drinks marketed in Lagos, Nigeria. African Journal of Biotechnology, 11(20), 4676-4680.

26. Engwa, A. G., Ihekwoaba, V., Ilo, U. S., Unaegbu, M., Ayuk, E. L., \& Osuji, A. G. (2015). "Determination of some soft drink constituents and contamination by some heavy metals in Nigeria" Elsevier Toxicology Reports, 2, 384390 . 